\title{
Mothers and Sons in Early Imperial China
}

Mère et fils dans la Chine ancienne

中國古代的母子

Mark Edward Lewis

\section{CpenEdition}

Journals

Electronic version

URL: http://journals.openedition.org/extremeorient/226

DOI: $10.4000 /$ extremeorient.226

ISSN: 2108-7105

\section{Publisher}

Presses universitaires de Vincennes

\section{Printed version}

Date of publication: 1 January 2012

Number of pages: $245-276$

ISSN: 0754-5010

\section{Electronic reference}

Mark Edward Lewis, " Mothers and Sons in Early Imperial China », Extrême-Orient Extrême-Occident [Online], Hors-série | 2012, Online since 01 January 2015, connection on 19 April 2019. URL : http:// journals.openedition.org/extremeorient/226 ; DOI : 10.4000/extremeorient.226 


\title{
Mothers and Sons in Early Imperial China
}

\author{
Mark Edward Lewis
}

While this issue of Extrême-Orient, Extrême-Occident is devoted to the theme of fathers, their role in the family can only be understood as part of a system of relationships including wives, concubines, mothers, sons, and siblings. This article will focus on evidence of a shifting balance of power within the household, and secondarily within the lineage, that entailed a relative rise in the position of the mother (or rather mothers, as most elite households had concubines who could play an important role in the politics of the household). As I will elaborate below, this rise of maternal status and power took the form of an increasing emphasis on the household as an "emotional community," in which relations and hierarchy were determined equally or more by the emotional bonds between individuals than by their hierarchical relations as stipulated in the formal ties that constituted the lineage. ${ }^{1}$ This development, which can be textually discerned from the second half of the second century A.D. through the fifth century, marked not only an important step in the development of the family unit in China, but also a significant stage in China's history of emotions.

As has been demonstrated elsewhere, the primary unit of early imperial Chinese kinship organization was the residential household. For poor families, this would consist of a married couple, their offspring, and sometimes an older parent. For wealthier families, a family could also include several secondary wives, servants, and retainers. While poor families would seldom be able to trace their descent further back than one or two generations, and hence were unable to recognize large numbers of kin beyond the household, wealthier families preserved in their ancestral cult the memory of several generations, and hence could identify larger number of kin who were not co-resident. The lineage was primarily a male

1. On "emotional communities" as a unit of analysis for the study of societies and emotions, see Rosenwein (2006). She defines "emotional communities" as "groups in which people adhere to the same norms of emotional expression and value - or devalue - the same or related emotions." See 2, 23-27, 109, 164-167, 188-189. 
construct, defined by transmission from fathers to sons, while women figured only as ritual adjuncts of their husbands who were entitled to receive sacrifice only due to their role in the physical generation of sons. In the household, in contrast, while the mother was theoretically completely subordinated to her husband, she wielded considerable authority through her power over her sons. ${ }^{2}$

While such power, and the threats that it posed to patriarchal power and the lineage, is reflected in scattered anecdotes (above all those dealing with empresses and empress dowagers) from the beginnings of the empire, it remains largely invisible until the second century A.D. From that time, and over the next few centuries, the power of mothers and its basis in their close physical and emotional ties to their sons, are elaborated in a range of inscriptional, commentarial, and literary materials. To some degree this development could be interpreted as simply reflecting the emergence of new genres that depicted aspects of life that had hitherto gone unnoticed. While this is no doubt part of the explanation, I would also argue that the emergence of these genres, and the centrality that they grant to emotional ties as constitutive of kin bonds, in themselves indicate the increasing cultural centrality of such emotions, and further indicate a redefinition of the household-based kin group as an emotional community.

The earliest genre that made a central, recurrent theme of the emotional ties of sons and mothers was the Eastern Han funerary inscription. While a few inscriptions are earlier, they survive in significant numbers only from the second century A.D., and the vast majority date from after 150 A.D. ${ }^{3}$ These inscriptions were crafted literary and poetic works, usually composed by celebrated writers and physically written by eminent calligraphers who were recruited for the purpose, and under whose names the texts would circulate and ultimately be gathered in collections.

As Miranda Brown has argued, the best explanation for the emergence of this new genre, in which what had been private or personal matters became the topic of literary depiction and society-wide distribution, was the increasing emphasis on devotion to one's family as both a hallmark of elite status and a necessary attribute for appointment to office. Whereas most Western Han writers on filial piety (of an admittedly small sample) had argued that the highest expression of this virtue was serving the ruler, Eastern Han writers almost all insisted that it was the service and mourning of his own parents that identified the filial son. This increased emphasis on devotion to one's parents as the measure of virtue was also manifested in the increased attention to lavish funerals, protracted periods

2. For a synthetic treatment of related issues, see Lewis (2006a): chap. 2. On the power of mothers in the household, and how this presented a problem or threat, see 106-115.

3. This discussion draws heavily on Brown (2007): chap. 2, 3. 
of ascetic mourning, and debates over whether such displays were genuine. ${ }^{4}$ This new emphasis on devotion to the family over devotion to the state, in turn, was linked to hostility to the eunuch-dominated court and interest in local society in the period when the inscriptions were written.

One of the most striking features of these funerary inscriptions is that they depict a completely different vision of the family than that defined by the formal rules of mourning relations articulated in the ritual classics. These rules defined hierarchically differentiated categories of kin in terms of the periods for which mourning was required (with closer kin marked by longer periods) and the type of clothing to be worn while in mourning (with closer kin marked by coarser clothes). People who were not within the stipulated bonds of mourning were not technically kin.

The divergence between the system of relations defined by ritual mourning and those articulated in the inscriptions can be seen in the case of children. Within this system, children who died before the age of five (six as counted by the Chinese) were not entitled to formal mourning, although a brief period of weeping was permitted. Nevertheless, several funerary inscriptions were devoted to children who died young, and these often highlight the powerful emotions felt by the surviving kin:

His loving mother was pained with grief;

His elder siblings longed for him,

Moved by their closeness and love from his infancy.

Though regretting the distance from the capital,

They opted for what was expedient

Burying him beside the tombs of his two ancestors.

A relative, $\mathrm{Li}$ Tao, and others,

Collectively recalling with longing the late gentleman,

Lamented the passing of his offspring,

Erected this stele, carved these words,

In order to console their mourning and longing...

Alas, this child died young,

Wounding the liver-feelings of his loving mother.

He follows his august ancestors to the realm of the spirits,

May the multitude of souls give him peace

While our tears pour down in sorrow, alas! ${ }^{5}$

4. This increased attention to, and debates over, public displays of mourning is discussed in many sources, e.g. Ebrey (1986); Brown (2007): 51-59.

5. Cai Yong 蔡邑 (133-192), Cai Zhonglang ji 蔡中郎集, “Tongyou Hu Gen Beiming 童 幼胡 根碑銘," SBBY ed., vol. VI, 4b-5b. Cai Yong was the most celebrated composer of funerary inscriptions, and his literary collection is one of our best sources for them. For a similar inscription, see Wu Hong (1995a): 80-81. 
Other inscriptions depict grief over the deaths of siblings, uncles, aunts, and every category of kin. In this way they give dramatic expression to the emergence of an idea of families as units constituted by powerful emotions that are to be publically displayed.

While the inscriptions depict emotional ties as constitutive of the family, they are particularly striking in their emphasis on the mother-son tie. In terms of the formal relations of mourning in the ritual classics, this tie was significant, but always subordinated to that of the father and son. Thus an heir's mourning for a father (the most important and detailed son-father mourning elaborated) entailed three-years mourning with frayed sleeves. In practice, this meant not working for twenty-five months, while living in a hut, eating a restricted diet, and wearing the stipulated garment. If the mother died while the father was still alive, the son was to observe only three months of mourning, because a longer period would disrupt the service of his father. If the father had died, then the mother inherited his role as senior person in the household, and was then entitled to the three-year period of mourning, but with a garment of hemmed sleeves. A mother who had been divorced was to receive no mourning whatsoever. These texts state explicitly that the father is the "most venerated [zhi $z u n$ ]," while the son's respect for his mother is purely a "private veneration [si zun]." Other texts go so far as to argue that mothers were not venerated but "intimate [qin]," while fathers were "venerated but not intimate." 6 These and related texts elaborate the idea that the father, as the supreme authority in the household, is the recipient of the supreme devotion and the highest mourning. Mourning was to be a performance that instantiated hierarchy and authority.

However, in the household as an emotional community that emerged in the Eastern Han inscriptions, the significance of mourning is different. First, as Miranda Brown has pointed out, in available Eastern Han sources, records of sons wearing mourning for their mothers, burying them, and expressing grief over their deaths outnumber such records for fathers by a factor of two and half to one. More significantly, accounts of mourning for fathers tend to be brief and formulaic. In literary sources they generally stipulate that the requirements of ritual were fully observed, and at most note that the son grew "emaciated" due to the reduced diet. Inscriptions on the topic similarly tend to be brief and often mention a father's death only to account for an interruption in his son's career.

6. Yi li zhu shu (1974): “Sang fu 坒服," chap. 29, 1a-4a; chap. 30, 2a-3a, 6a-6b; Li ji zhushu (1974): “Sang fu xiao ji 喪服小記,” chap. 32, 4b-5b; “Biao ji 表記”, chap. 54, 14b-15b; “Sang fu si zhi 喊服四制,” chap. 63, 12b-13a. On the mourning obligations of men who were not noble heirs, see Li ji zhushu (1974): “Wen sang 問喪," chap. 56, 13b-17a. While some texts suggest that fathers were "not intimate" others describe them as the "most intimate”. See, for example, Nan shi 南史, by Li Yanshou (1975): chap. 73, 1808. 
Even one of the rare inscriptions that mentions how much a man wept for his father goes on immediately to note that he was "cautious in observing the old rules [of mourning ritual]" and returned immediately to office. ${ }^{7}$

Depictions of mourning for mothers, on the other hand, insist on the highly emotional character of the son's response. Thus one literary account notes that when two brothers, both members of the imperial Liu clan, learned of the death of their mother they both "spat blood and damaged the corners of their eyes [from weeping]." Only after this outpouring of extreme grief did they turn to the mourning for their father, and the text provides no description of that process. ${ }^{8}$ Such records are particularly significant in that theoretical accounts of the purpose of ritual routinely argue that the sages created it precisely to avoid such extreme actions as those described here. Thus the new emotive realm of the household not only inverted earlier gender hierarchies, but also posited an entirely new standard for judging mourning, a standard that overturned the conventional rationalization of funerary rituals.

Several funerary inscriptions are even more extreme than the literary records in their accounts of the emotional responses of sons to their mother's death. Thus the inscription of the eunuch Cao Teng read:

Meeting the sorrow of losing his mother,

His filial conduct was sincere.

But he was not careful with respect to the ritual rules,

For in his mourning he was excessively grieved.

Even after [changing] his garments for the annual xiang sacrifice,

He could not bear the separation from this object of gratitude.

His feelings [...], and he fell ill;

His life force destroyed, he prematurely died. ${ }^{9}$

Here the extremes of emotional mourning are explicitly said to exceed the dictates of ritual to such an extent that Cao Teng dies of his grief. Nevertheless, the inscription approvingly presents this as a measure of his devotion to his mother.

While Cao Teng's inscription is probably the boldest and most extreme depiction of strong emotions as constitutive of familial bonds, several inscriptions composed by the leading author and calligrapher Cai Yong (A.D. 133-192) provide more refined and skillful depictions of feeling. Rather than directly asserting the extremity of sons' grief, he utilizes the indirection so highly prized in Chinese writing to attain a greater emotional impact on his readers. Thus in

7. Brown (2007): 66, 75-76.

8. Fan Ye (1984): chap. 42, 1426.

9. Hong Gua, Li shi: “Bitinghou Cao Teng beiyin 費亭侯曹滕碑陰,” chap. 15, 3b. Cao Teng adopted the father of Cao Cao (A.D. 155-220) who later established the Wei Dynasty. 
an inscription that he wrote on behalf of her two sons for Ma Lun (A.D. 122184), Cai Yong wrote:

Gone and not to return,

Sunken deep into the great darkness,

Alas, Sorrowful indeed!

Her tables and mats are set in vain,

Her curtains and canopies set out to no avail.

Her things are still there,

But we do not see her person.

Her ghost floats about;

How can we pacify her spirit? ${ }^{10}$

Rather than announcing that they fulfilled the mourning requirements, or asserting their great grief, Cai Yong imaginatively places himself within the lived experience of the two mourning sons, who remain haunted by the everyday objects associated with their mother, objects whose presence suggests the similar presence of a wandering, unhappy spirit.

Yet another inscription by the same author dramatizes the entire process of dying, tracing the stages both of the mother's physical decline and her sons' ever increasing despair:

Bright Heaven does not pity,

But inflicts on us this crippling disaster.

Bed-ridden with an incurable disease,

Her spirit was enfeebled and hurt.

Grieved were the filial sons,

Very fearful, very worried.

There was no divinity they did not invoke,

No medicine they did not bestow.

Alas, what a great sorrow indeed!

Thereupon, the filial sons wailed so long that

Her breath, cut off, might be again revived.

Howling and wailing, they proclaimed their grief,

Not knowing what crime they had committed.

May Bright Heaven, Lord on High,

Pity the orphans left behind,

Who seek, longing, for her wandering spirit.

How can we know where it has gone?

How sad, how pitiable! ${ }^{11}$

10. Cai Yong, Cai Zhonglang ji, “Situ Yuan Gong furen Ma shi beiming 司徒袁公夫人馬 氏碑銘," chap. 6, 5b-6b.

11. Cai Yong, Cai Zhonglang ji, “Jibei xiang Cui jun furen lei 済北相崔君夫人昩,” chap. 6, 6b-9a. 
This inscription traces out the entire process of death as a psychological experience for the survivors, beginning with anger at the injustice of Heaven, then tracing the failure of all religious and medical procedures to halt the decline, portraying the ritual to call back the soul (with the suggestion that the sheer energy of the sons' wailing might somehow put breath back in their mother's body), and finally ending in self-blame and despair.

Before proceeding, it is important to note that we cannot assume that these descriptions of intense emotional suffering for dead mothers or young children depict the actual experiences or feelings of the mourners. The mourning inscriptions were collective productions whose composition passed through multiple hands, and which were intended for public consumption by the mourners' friends and peers. What the mourners actual felt cannot be known. What is significant here is that numerous members of the late Han elite chose to publically proclaim intense emotional responses to the deaths of their mothers (and under-age children), people who in the conventional mourning system were secondary or marginal. Both the intensity of the emotion and its target were new, and that novelty is significant.

A second literary topos that suggests the revaluation of mother-son emotional bonds is the revaluation of the debts of gratitude (en) that linked them. As I demonstrated in The Construction of Space in Early China, several tales collected in the Biographies of Eminent Women (Lie nü zhuan) and other sources deal with the problem of the stepmother. Such stories contrasted the bonds of a woman with her own children, bonds defined as "private love [si ai]," "intimacy [qin]," or "kindness [en]," with her duty towards the children of the first wife, defined as "public duty [gong yi]." 12 These stories celebrated women for abandoning the emotional ties that bound them to their own children in order to protect the children of the first wife, i.e. in order to serve the interests of the lineage into which she had married.

However, in the Eastern Han the same rhetoric emphasizing the emotional bonds of mothers to their offspring was often given a positive revalorization, especially in defending the interests of the imperial affines who came to dominate the court through the power of dowager empresses over their youthful sons who ruled as emperor. Thus a memorial by Shentu Gang criticizing Wang Mang, who soon tried to found his own dynasty, for cutting off the boy Emperor Ping from his maternal relatives said:

12. Lewis (2006a): 108-110. In addition to the stories cited here, which are largely fictional/ exemplary, Jin shu gives a historical case of a second wife who when both her own child and that of the first wife fell ill, chose to sacrifice her own. See Fang Xuanling et al. (1974): chap. 34, 1024. For a story in the same book in which the evil stepmother attempts to destroy the filial son of the first wife, see chap. 33, 987. 
The natural relation of children to mothers is that through the Way of Heaven they are the supremely intimate [zhi qin]. Now the sage ruler [Emperor Ping] is still a small child, barely out of swaddling clothes. Since he was installed, he has been cut off from those who are most intimate with him. Being separated from his maternal relatives, the bonds of kindness/gratitude [en] cannot connect. ${ }^{13}$

The phrase zhi qin was frequently applied to the relation of sons to their fathers in Warring States and Western Han texts, but in the Eastern Han it came to be almost exclusively applied to the mother-son bond, while fathers were increasingly identified with "reverence" and "duty". ${ }^{14}$ Thus, during the era of powerful imperial affines, appeals to the love and intimacy that emotionally bound mothers and sons became largely positive. This was particularly true in the rhetoric of those who attacked eunuch influence, which routinely was in rivalry with the power of affines as well as the formal court, but was even invoked against the power of the affines, where that was based on separating the emperor from his birth mother. ${ }^{15}$

It is noteworthy that this political revaluation of the physical and emotional bond between mother and son was linked to the rise of institutionalized maternal power at court, for the majority of the funerary inscriptions were produced in the same period. Thus although they were political rivals, several major parties at court and many families who were banned from taking office, or who had voluntarily shifted their center of activity from the court to local society, were joined in a common elevation of the maternal role, and of the emotional bonds that constituted its power.

A third discourse that developed in the same period was an increasing insistence on the shared physical substance of mother and sons, often described as their possessing a "shared material energy/substance [tong qi]." This image was already applied in a memorial to the dowager empress in the late Western Han, asking that she discipline a particularly ill-behaved son. Using rhetoric much like that in the nearly contemporary petition to Wang Mang cited above, the writer describes the child in question as a "sage ruler" who "has just gone from swaddling clothes to the ruler's position," and proceeds:

Within the women's quarters, the relation between mother and son is that of different breaths of the same breath/energy, the kindness/gratitude of common bone and flesh [tong qi yi xi, gu rou zhi en]. How could he ignore you! How could he ignore you! ${ }^{16}$

13. Fan Ye (1984): chap. 29, 1012.

14. Brown (2007): 68-71, 161 notes 20, 29.

15. For an example of the latter, see Fan Ye (1984): chap. 7, 305. For the former, see Fan Ye (1984): chap. 78, 2526.

16. Ban Gu et al. (1994): chap. 80, 3322. 
Here the idea of the unique intimacy of mothers and sons is expressed through the image of their sharing a common substance, both the dynamic energies of $q i$ and the cruder flesh and bone.

The locus classicus for the phrase tong qi yi xi to describe the intimate bonds of mother and son is in the Springs and Autumns of Master Lü:

In Zhou there was a man named Shen Xi who had been separated from his mother [since childhood]. He heard a beggar singing at his gate, and it deeply grieved him, so that his visage trembled. He asked his gatekeeper to bring in the singer. He met with her and asked, "Why are you begging?" When she told him her story, it turned out to be his mother [...]. Two parts of one body, different breaths of the same breath/ energy, like grasses having stalks and flowers or trees having roots and trunks, even if in separate places they are connected [tong]. Their hidden intents [zhi] come together; they treat each other's ailments; they are stirred [gan] by each other worries. When alive they delight in each other, and when dead they mourn each other. This is what is called "the intimacy [qin] of flesh and bone." 17

This story posits a unique capacity of recognition based on the common substance of the mother and son. It is noteworthy that their common $q i$ is revealed in the act of singing, for breathing, music, and verse were all understood as aspects of $q i$ energetics. The reference to $z h i$ "fixed intent" also ties the story to ideas of the recognition of character or true identity as revealed in verse performances. ${ }^{18}$ The passage is also of interest for its use of vegetation to provide a natural image for energetic links across a distance that allow for mutual interaction of what appear to be distinct objects, but are in fact a single physical unit. In any case, the story appeared in Western Han philosophical works, which cited it only in brief or fragmentary form, indicating that it was well-known. ${ }^{19}$

However, the most famous use of the image of mother and son as sharing a single $q i$, one which became a virtual myth for this theme that was elaborated down the centuries, was the Eastern Han author Wang Chong's (A.D. 27-ca 100) account of the relation between Master Zeng, Confucius's disciple who had become the archetypal exponent of filial piety, and his mother:

A transmitted text says, "Master Zeng's filiality was such that he shared a common material substance/energy [qi] with his mother. Master Zeng went out to gather firewood in the wilds, and a guest came who was then about to depart. Master Zeng's mother said, 'I hope that you will stay. Shen [Master Zeng] is about to arrive back.'

17. Lü shi chun qiu jishi (1984): chap. 9, 509. The story immediately preceding that of Shen Xi also tells of the separation of a son and his mother, but it deals with the capacity of emotions to find expression in music, rather than on the distinctive character of maternal ties.

18. Lewis (1999): 155-163.

19. See, for example, Huainanzi (1974): chap. 10, 159; chap. 16, 271. 
She immediately pinched her left arm with her right hand's fingers. Master Zeng's left arm immediately hurt, so he dashed back, and asked his mother, 'Why did your arm hurt?' His mother said, 'Just now a guest arrived, who was about to depart, so I just pinched my arm to summon you. That's all it was." Probably on account of his supreme filiality he shared a common substance/energy with his mother, so if her bones had any ailment, his spirit would be stirred [gan] by it. ${ }^{20}$

This story carried forward the idea of mothers and sons being linked by a common substance, presumably dating back to the period when the child in the womb and his mother formed a single physical unit, but it develops this idea in several notable directions.

First, the reference to an earlier work shows that the story already had some degree of circulation by the second half of the first century A.D. Second, whereas the earlier passage used the idea of common substance as an image of closeness, here the idea of a common substance acting as a channel for physical communication comes to the fore. Third, the communication is not an abstract, mental telepathy but a neural bond of shared pain, which serves to elicit the mutual protective responses that define the kin relationship. Finally, through using the verb gan to describe what is taking place, Wang Chong alludes to the idea of "stimulus-response [gan ying]" which was fundamental to Han cosmology and political thought. This idea was the fundamental model in the period for all action at a distance, but it was above all used in the argument that political actions and conditions would elicit resonant responses in the natural world. Thus the use of the term gan here grants the mother-son tie a cosmic status, and gives it a centrality equivalent to the role of the Son of Heaven. This idea is also dramatized in several stories from this period in which auspicious plants and creatures - a phoenix, dodder climbing up a mourning hut, intertwined trees - miraculously appear in response to unsurpassed filiality exemplified by devoted mourning, or by a son's protection of his mother's tomb from earthquake or fire. ${ }^{21}$

This idea applies to mother-son relations an idea that had been articulated about filiality in the canonical Classic of Filial Piety:

Reaching its highest point [zhi], filial piety and brotherly affection reach to the spirits [shen ming]. There is nothing they do not penetrate $[$ tong $] .^{22}$

20. Wang Chong 王充 (1957): chap. 5, 116.

21. Ban Gu et al. (1975): chap. 16, 21b-22a; chap. 19, 14a; Fan Ye (1984): chap. 39, 1312; chap. 60b, 1980 - this second account of Heaven's response to filial mourning for a mother refers to the case of Cai Yong, who composed many of the inscriptions cited above; Xie Cheng 謝承 (1972): chap. 7, 16a.

22. Xiao jing zhushu (1976): chap. 8, 2a. 
Wang Chong explicitly cites this passage as the origin of the story of Master Zeng and his mother. He argues that the passage originally only refers to the transforming power of moral virtue, but that the simpleminded people of the world misunderstood it as referring to a magical power of filial piety. They then attributed this power to Master Zeng who was commonly reputed to be the most filial of all. ${ }^{23}$ However, Wang Chong's skeptical argument assumes a widespread, nearly universal belief in the extraordinary power of the mother-son tie. It is also noteworthy that this abstract assertion of the power of filial piety to move the gods is transferred to the realm of mother-son relations by assigning it a physical form, thus linking it to the bodily realm where the mother's unique role was most explicit.

The story of the magical bond between Master Zeng and his mother was carried forward and developed in the later Chinese storytelling tradition. The story with almost no change was told of Cai Shun, a famous exemplar of filial piety who lived in the second half of the first century A.D. ${ }^{24}$ Two centuries later, Gan Bao (fl. A.D. 317-322) in his Record of Collecting Spirits [Sou shen $j i]$ gave the following version:

Master Zeng was accompanying Confucius to the state of Chu [in the far south] and his heart suddenly stirred. He said farewell, returned home, and asked his mother what had happened. She said, "I longed for you, so I bit my finger." Confucius said, "Zeng Shen's filiality means that his spirit is stirred [gan] across ten thousand $l i . "{ }^{25}$

The story varies from Wang Chong's in two significant ways. First, the direct translation of pain from the spot on the mother's body to that on the son's here becomes a more general mental unease. Second, and more important, the geographic range here is extended, figuratively to the edges of the earth. This thereby gives a direct expression to the Classic of Filial Piety's assertion of the universal range of true filial piety.

The Record of Collecting Spirits is also of significance to the evolution of the story of Master Zeng and his mother, because we again see the story manifesting

23. Wang Chong (1957): 116-117.

24. Fan Ye (1984): chap. 39, 1312. In addition to the story of his mother biting her finger to summon him, Fan Ye's account of Cai Shun also tells how, when a fire swept through his village, he embraced his mother's coffin and prayed Heaven to spare it. While the neighboring houses were burned, Cai Shun's was spared. It also tells how, because his mother had feared thunder and earthquakes while still alive, whenever these occurred he would run to her grave and weep, "I am here." Although offered a government post, he declined because it would entail leaving his mother's grave.

25. Chap. 11, 133. 
itself in accounts of other mother-son pairs. Thus immediately following his version of Master Zeng's story, Gan Bao includes the following story:

Zhou Chang was by nature kind and loving, and when young he was supremely filial. He lived alone with his mother. Whenever he went out and his mother wanted to call him, she would always bite her hand. Chang would immediately feel the pain in his hand and come back. ${ }^{26}$

The significance of this story is that it shows that by a century after the fall of the Han dynasty the story of Master Zeng and his mother (as earlier also applied to Cai Shun) had become a generic template that could be attached to any exemplary case of filial piety. To the extent that a son was truly filial, it would be manifested in a superhuman sensitivity to the pains or needs of his mother.

Stories of this nature subsequently even began to proliferate in the official dynastic histories, which gave them an imprimatur for veracity that would not necessarily have been enjoyed by Wang Chong's transmitted story (which he himself dismissed as nonsense), or Gan Bao's ghost stories. Thus the Book of the Liang Dynasty contains the following stories:

Zang Dun was filial by nature. He accompanied his father to keep watch through the night when the former was imprisoned, while his mother Madam Liu remained at home. In the night she suddenly died, and Dun's middle finger on his left hand immediately hurt, so that he could not sleep. At daylight the letter from home reported the sad tidings. His being stirred to [hidden] communication [gan tong] reached to this extent.

Ruan Xiaoxu ["filial thread"] was studying at Zhongshan. His mother Madam Wang suddenly fell ill, so Xiaoxu's siblings wanted to summon him. His mother said, "Xiaoxu by nature has supreme powers of hidden/spirit communication [ming tong]. He will certainly come of his own accord." As she predicted, his heart became alarmed and he returned. The neighbors all sighed in wonder at it. ${ }^{27}$

These stories, and contemporary ones from the histories of the Northern Dynasties, are notable in that the mother-son bond is demonstrated not by the mother's deliberately hurting herself to attract a remote son's attention, but rather by her falling ill or even dying. ${ }^{28}$ This assimilates the stories more explicitly to

26. Gan Bao (1979): chap. 11, 134.

27. Yao Cha and Yao Silian (1973): chap. 42, 600; chap. 51, 740. While this history was not compiled until the early Tang, there is no reason to doubt that much of the material came into existence in the period with which the history deals.

28. See, for example, Linghu Defen et al. (1971), chap. 12, 196: “[Yuwen] Xian was supremely filial, and was famous for serving his mother. She had long suffered fevers that caused her to repeatedly tremble, and Xian directly served her, without even loosening 
accounts of sons who proved their filial piety by the diligence of their care for their mother, or by the passion of their mourning. The second story is also notable in that the mother explicitly argues that her filial son will certainly be magically moved by her condition, thus reinforcing the idea of how conventional this sort of story had become by the middle of the centuries of disunion. Interestingly, the earliest story that I have found of any such miraculous connection between fathers and sons only appears at this time, some five centuries later than those pertaining to mothers. ${ }^{29}$

In the same period there also emerged several stories in which it was the mother's body that was magically affected by a misfortune that had befallen her son, rather than the reverse. Thus the Book of the [Liu]-Song Dynasty by Shen Yue (A.D. 441-513) records the following story:

[Zhu] Xiuzhi was encamped at Huatai, where he was besieged by the barbarians [the Northern Wei forces]. After several months his grain ran out, so that his men cooked rats and ate them. Finally, they fell to the Wei. In the beginning, when Xiuzhi's mother heard that he had been besieged for a long time, she constantly worried about him. One day her breast milk suddenly began to flow. Weeping and wailing she said to her household, "I am already old, and suddenly I again have breast milk. This is inauspicious. Might my son have suffered some loss?" When she subsequently made enquiries, it turned out that Xiuzhi had indeed been taken prisoner on that very day. ${ }^{30}$

The specific focus of this story on breast milk heightens the theme of the centrality of the mother's body to her intimate ties with her son, and gives physical expression to the idea of the exemplary mother's concern for the wellbeing of her son. While we know nothing about Zhu Xiuzhi's relation with his mother, it is notable that his biography describes him as "by nature stingy and cruel, and lacking in sentiments of gratitude [xing jian ke shao en qing]" and narrates how he refused to help his sister when she was collapsing from hunger and cold. Thus there is nothing to suggest that he was a filial son. Whereas the stories of filial sons being magically moved by their mother's pain or distress imply some degree of reciprocity, this story suggests that a mother might be moved by her

his belt. Sometimes he would travel east or west in state service, and every time his heart/mind became alarmed, it would invariably mean that his mother had fallen ill. He would then gallop back to enquire, and it was always as he had feared."

29. Yao Cha and Yao Silian (1973), chap. 47, 650-651: "Yu Qianlou's style name was Zizhen. He was a man of Xinye. His father's name was Yi... Yi fell ill at home. Qianlou's heart/mind was suddenly alarmed, so that his whole body burst into a sweat. That very day he resigned his post and returned home. The people in his household were all amazed that he had suddenly arrived."

30. Shen Yue (1974): chap. 76, 1969-1970. 
son's distress without regard to their relationship. This asymmetry in the story of the miraculous bonds of mothers and sons might be significant for ideas about the differences attributed to the two parties in the relationship.

While anecdotes of son's being magically moved by their father's sufferings appear quite late, another form of popular belief links fathers to sons through their shared physical substance. Several anecdotes refer to a "popular" idea that the blood of a son that was applied to the bone of his father would be soaked up, which was not the case for other bones. That this idea was indeed widespread is indicated by the fact that a man of humble origin, Sun Fazong, whose father had perished in the "Daoist" rebellion of Sun En at the beginning of the fifth century, dug up every skeleton he could find and tested it with his blood until "he had no intact flesh and his veins dried up." This unique bond between the substance of father and son was due to their "extreme closeness [zhi qin]." ${ }^{31}$ However, one should still note the contrast between the physical links of sons and mothers through common $q i$, which manifests itself in shared pain that makes possible intimate communication, and that of sons and fathers, who are linked by a common substance in the bone which had no emotional ramifications and which seems to be primarily an extension of the idea of a masculine ancestral line. It is significant that in late imperial China it was conventionally believed that woman's blood formed the child's flesh, while the father's semen formed his bone. ${ }^{32}$

The new manner of writing the mother-son tie established in the Eastern Han inscriptions and anecdotes was extended in subsequent centuries in a variety of literary forms and ideas. First, as shown earlier, certain ideas on the intensity of the mother-son tie as exemplified in the story of Master Zeng and his mother were anecdotally elaborated and became commonplaces in the Northern and Southern Dynasties.

Another development in this period was the re-theorization of the nature of mourning ties, particularly those that existed between sons and mothers. As noted earlier, the ritual classics had assigned a fairly limited place to the mother, particularly while her husband was still alive. However, the late Eastern Han and

31. The story of Sun Fazong is cited in Li Yanshou (1975): chap. 73, 1808, which describes the belief as a "popular discourse [shi jian lun 世間論].” This belief is also cited in the story of Xiao Zong, where it is described as a "conventional [or 'vulgar'] theory [su shuo 俗說]." See Li Yanshou (1975): chap. 53, 1315-1316; Yao Cha and Yao Silian (1973): chap. 55, 823-824. The story of Xiao Zong is also significant in that the ghost of his decapitated father, whom he never knew, repeatedly appeared to him in a dream. However, he remains emotionally much closer to his mother, who accompanied him whenever he took up a post, and in front of whom he frequently "disported" naked above the waist, leading to gossip of incest.

32. Baptandier (2008): 66 and the works cited on that page. 
the Northern and Southern Dynasties witnessed a substantial re-interpretation of mourning obligations as part of a widespread interest in ritual theory within the "great families" that emerged in this period. As these families redefined themselves as a social group, many of their members reinterpreted the ritual classics to meet their own concerns and values. Much relevant material has been preserved in Tang encyclopedias, notably the Tong dian ${ }^{33}$ In this re-interpretation of mourning obligations, the physical and emotional bonds to mothers were given a central place.

The clearest examples of the re-interpretation of mother-son ties appear in discussions of the mourning obligations of an heir. These are the most striking cases because, according to early ritual theory, the status of the heir, who would become the head of the lineage, was absolutely central, and it superseded all honors owed to a mother based on her seniority in years and the fact that she had given birth to him. This sort of case was particularly noteworthy when the mother was a concubine whose son had become heir due to the lack of a son born to the primary wife. Also worthy of note as demonstrations of the new emphasis on the physical/emotional ties of mother and son are debates over mourning a mother who had been divorced. Such cases placed in the balance the relative importance of the authority of the father, who in the act of divorce had decreed that the physical mother was no longer the true mother, against the actual physical link established by the fact of birth. I will here present examples of the debate over how such cases should be handled.

In the Han and subsequent dynasties, the rules on sons of concubines mourning their mothers followed the ritual classics. These stipulated that if the father was dead, the mother received three years of mourning, if he was alive then one year, and if the son became an heir then only three months. One issue not discussed in the classics, but debated in the Wei and Jin dynasties, was whether the fact that a primary wife was still alive should, like the case of the father, reduce the mourning period owed to a concubine by her sons. One scholar wrote:

A son of a concubine mourning his mother is due to the fact that they shared chambers and he follows his emotions [...]. How on the basis of citing the father's case as a precedent could we reduce a son's period of mourning? ?4

Here the physical and emotional circumstances of the son are granted priority over the mother's familial status. Since the question of clearly separating the concubines from the primary wife was of great importance, the argument that it was not relevant in comparison with physical and emotional bonds was not trivial. ${ }^{35}$

33. On this development, see Kaga Eiji (1964).

34. Du You (1988): chap. 94, 2545-2546. The passage quoted is on 2545.

35. On the importance of the distinction of concubine and primary wife in the subsequent Tang Dynasty, see Lewis (2009b): 186-189. Of course, the refusal to accept an analogy between husband and primary wife might also indicate that this was regarded as a derogation of the husband's unique status. 
However, the primary arguments dealt with the level of the enfeoffed nobility, where the question of being an heir was particularly important. Quite a few such cases figure in the historical records, and substantial debates are preserved. Here I will only touch on a few examples and how they were handled. One of the earliest cases occurred in A.D. 268, when officials urged Emperor Wu of the Jin (r. 265-290) to cut short his period of mourning for his mother. Outraged at the suggestion, he argued:

Having received the love of an entire lifetime, without repaying it with a few years' mourning, to just bury her and immediately revert to normal life, this is something that my feelings could not bear. ${ }^{36}$

Although ultimately forced to accede, the emperor persisted in wearing a simple cap and eating only vegetables for the full three years, following the pattern of mourning for his father.

Two notable cases involved sons of Emperor Yuan of the Jin (r. 317-323), the man who had established the Jin regime in the south after the loss of Chang'an and Luoyang. Two of his sons by concubines, Sima Yu and Sima Xi, were established as kings (wang) when they were still children. The mother of Sima Yu, the future Emperor Jianwen (r. 371-372), died when Yu was only seven years old. Sima Yu petitioned to observe a full three-year mourning period, citing the fact that he had lived together with his mother his entire life, and inappropriately citing a precedent regarding full mourning for a mother who had been the primary wife. When the petition was rejected, he continued to "howl piteously" and even "wept blood," insisting on a full mourning period. Ultimately the court acceded, and manipulated the case by establishing a new kingship for him (thus making him no longer an heir) and posthumously elevating his mother's rank. ${ }^{37}$

Sima Yu's half-brother, Sima Xi, likewise petitioned to follow a full threeyear mourning period for his concubine birth mother. This elicited a major debate at court, and the opinions of five different officials are preserved in the Tong dian. ${ }^{38}$ Two argued that he should mourn for one year, two for only three months, and one for five months. Notably, those who argued for a full year posited two major grounds. First, they advocated the doctrine that "the mother is ennobled by the [rank of the] son. [mu yi zi gui]." Second, they argued that given the ennoblement of the mother, the son should "be able to follow his

36. Shen Yue (1974): chap. 15, 391.

37. Du You (1988): chap. 82, 2230; Fang Xuanling et al. (1974): chap. 8, 219; chap. 32b, 971, 979-980.

38. Du You (1988): chap. 82, 2229-2230. 
personal feelings [de sui xi qing]." However, since he had been established as an heir, the full mourning should be reduced by one degree to a period of one year.

The idea that the son ennobled the mother had no canonical grounding in the ritual classics, but was based on a story in the Spring and Autumn Annals as glossed in the fourth-century B.C. Transmission of Master Zuo and the thirdcentury B.C. Transmission of Master Gongyang. This recorded how a concubine of the lord of Lu was raised in rank when her son assumed the throne, and promoted again in the sacrifices offered to her spirit. ${ }^{39}$ The idea that the son and his mother were inextricably tied, so that the ascent of one entailed the rise of the other, became an important argument in strengthening social recognition of the mother-son tie. Its link here to the emphasis on the "personal emotions" that bound son to mother is also significant.

Those arguing for the shorter periods of mourning based this on the canonical strictures limiting the mourning of sons who had become heirs to their concubine mothers. The emperor concurred with these arguments, and decreed that Sima Xi should mourn for only three months. However, the latter refused, and sent up a series of memorials insisting on the full period. Finally, he submitted, accepting that he "did not dare to harm the royal constitution by insisting on following his personal desires [bu gan zhi sui si huai, yi que wang xian]." However, while ostensibly abandoning his own desires in the name of public order, Sima Xi proceeded to mourn his mother for nine months, rather than the decreed three. ${ }^{40}$

Shortly before the above cases, the official Gu He had impeached a king and a duke for observing three-year mourning for concubine mothers. He described what happened as follows:

One who becomes an heir reduces the mourning period for his birth mother. This is to remove the closeness of one's natural ties, in order to make clear the highest public duty [zhi gong zhi yi]. The passages on this reduction are clearly written in the Zhou classics [...]. Now in recently mourning for their birth mothers, [these nobles] have followed the full period of mourning. They have violated proper ritual degree in order to give full vent to their private feelings [si qi si qing]. Those in the streets and alleys have endorsed their excesses, and among those who discuss it there is none who criticizes them. [...] You should send down the Minister of Rites to have them end their mourning, and if they do not respect your command then strip them of their ranks. ${ }^{41}$

39. Сhип qіи Zио zhuan zhu (1981): Lord Wen year 4, 532, 536, 538; Lord Wen year 9, 571, 574; Chun qiu Gongyang zhuan 公羊傳, in Shisan jing zhushu, vol. VII, ch. 13, 10b, 19a-b.

40. Fang Xuanling et al. (1974): chap. 20, 629.

41. Fang Xuanling et al. (1974): chap. 83, 2165-2166. 
This memorial is remarkable for several features. First, it shows that the pattern of members of the imperial family and the nobility insisting on observing full mourning for their natural mothers without consideration of their rank had become very widespread. Second, Gu He believed that such conduct was not merely widespread, but virtually universally approved. Third, he takes it as a real possibility that the sons in question would ignore an imperial decree, and the aforementioned conduct of Sima Xi confirms this possibility.

In A.D. $392 \mathrm{Ju}$ Yi sent up a memorial arguing that from the highest levels of the nobility down through the ranks of the bureaucracy, sons of concubines who had become heirs were "giving full vent to their private feelings" by observing full mourning for their mothers, whom they treated in the same way as the primary wife. When the court ignored the memorial, he sent up another one the following year that enumerated some cases and then went on:

In ancient classics or modern institutions, there is nothing about three-year mourning [for birth mothers]. However, in recent years everyone is giving free rein to their private feelings, each imitating and following the other, so that it has gradually become a custom [ $s u$ 俗]. If you let it take place and do not ban the practice, the sage canon will be destroyed. ${ }^{42}$

However, these prophecies of social collapse had little effect. Not only had the belief in full mourning for concubine birth mothers of heirs become widespread (if not universal), but the ruling emperor himself was the son and grandson of concubines, and in A.D. 394 he granted both of these women the title of empress dowager. ${ }^{43}$ This formal recognition of a concubine as empress dowager was without precedent in the Jin dynasty, and in the decree responding to Ju Yi the emperor extended the official mourning period for a concubine mother of an heir from three months to nine, thereby recognizing that conventional practice had to some degree superseded the ritual classics. ${ }^{44}$ Even this attempt at a compromise had little effect, for an essay written by Yu Weizhi in the subsequent Liu-Song dynasty stated that in spite of the canonical three months and the Jin decree for nine months, in practice everyone continued to mourn for three years. Some ritual officials at the Song court even advocated the formal recognition of this practice..$^{45}$

42. Fang Xuanling et al. (1974): chap. 20,628-629. The writer goes on to describe how the failure to properly check these emotions of sons for their birth mothers would destroy the reverence for the ancestral lineage and the rituals that bind ruler and minister.

43. Fang Xuanling et al. (1974): chap. 9, 240.

44. The titles granted to emperors' mothers and the debates with the court over the periods of mourning for them are enumerated in Fang Xuanling et al. (1974): chap. 31-32.

45. Du You (1988): chap. 82, 2227. For the remarks by Yu Weizhi 庵蔚之: Shen Yue (1974): chap. 15, 399-401. 
Perhaps the most extreme cases of the doctrine that a son ennobled the mother took place in the Northern Wei. Two emperors of this dynasty granted the title of "protecting dowager [bao tai hou]" and then "dowager empress [huang tai hou]" not to their birth mothers, but to their wet nurses. At the deaths of these women, in 440 and 460 respectively, the emperors declared that the entire empire should observe three days of mourning. ${ }^{46}$ Here a strong physical and emotional link, without the slightest religious or ritual sanction, became sufficient to turn a slave into an empress.

Another example of the increasing emphasis on mother-son emotional ties was the question of an heir's wearing mourning for a divorced mother. The ritual classics were clear that as the new head and embodiment of the lineage, the heir could not wear mourning for a woman who, although physically and emotionally linked to him, was no longer a member of the lineage. ${ }^{47}$ However there is evidence that in the Wei and Jin dynasties this idea was modified in several ways. First, there is one case of a dying father calling back a divorced wife to help run the household because his current spouse was too young. The woman refused to participate in the household affairs or assist with preparation for sacrifices, but insisted she had returned only to take care of her own offspring. When dying, she demanded to be buried separately from the lineage. Although her son was head of the lineage which she had pointedly and repeatedly rejected, he still observed the full three-year mourning for his divorced mother, justifying it by his father's dying wish to call her back. His half-brother by the second wife, however, observed no mourning whatsoever, although since he was not lineage head he should have mourned for one year. While contemporaries debated how to judge the younger son's refusal, they do not seem to have questioned the lineage head's decision to observe full mourning for his divorced mother. ${ }^{48}$

In A.D. 249 the elder half-brother of the philosopher Zhong Hui also performed full mourning for his mother, who had been divorced and then immediately replaced by Hui's mother. This decision to mourn her was justified by the fact that she had no one who could make offerings to her spirit in her natal household. While this justification had no canonical grounding, some commentators accepted it as an extension of one's "sorrow" for someone who had no successors, i.e. on the basis of the strength of one's feelings. Indeed Cheng Xia went so far as to argue that since the ritual classics enjoined one to mourn for a stepfather, and in association with him for a mother who through this remarriage had left

46. Wei Shou (1974): chap. 13, 326, 327.

47. Yi li zhu shu (1974): "Sang fu," chap. 30, 7a; Li ji zhushu (1974): "Sang fu xiao ji," chap. $32,5 b$.

48. Du You (1988): chap. 94, 2550-2552. 
the lineage, it was incoherent for them to argue that one should not mourn for a divorced mother. In short, the classics were internally contradictory and consequently could be overruled. ${ }^{49}$ Writing shortly later, Yuan Jun argued:

Being the father's heir, the reason that you do not mourn a divorced mother is that those in mourning cannot offer sacrifice [the main ritual function of a lineage head]. On account of the divorce, one would have to reduce the level of mourning, but given that mother and son are the most intimate relations [ $z$ hi qin], how could one observe no mourning? It is proper for him to remove the mourning [that he is wearing for his divorced mother] and then sacrifice. ${ }^{50}$

While there is no solid evidence that an heir's mourning for a divorced mother had become conventional, like mourning for a concubine birth mother, it is clear that the practice existed, and that it had sufficient social support that several writers simply rejected the authority of the classics on this matter in support of the intimate, emotional bonds of mother and son.

One particularly striking case that elicited considerable discussion was Wang Shi, who in 320 wore mourning for a divorced stepmother. This woman had sons by a previous marriage, and when Wang Shi's father was dying she requested to return to her first husband's household, where ultimately she was buried. Since she had left with his father's consent, she was technically divorced and not entitled to mourning, but Wang Shi mourned her for one year. In the court debate about this case, two officials agreed that his behavior violated ritual strictures, but that it was justified because it was the outpouring of natural feeling. Thus Du Yi wrote:

Now Wang Shi could not bear his feelings of sorrow and desolation, so he followed his own ideas and violated the rites by wearing mourning for someone who was already cut off from mourning relations. This can be called "seeing his excess, you recognize his true humanity [guan guo zhi ren]." Bo Yu and $\mathrm{Zi} \mathrm{Lu}$ were disciples of the sage [Confucius]. $\mathrm{Zi} \mathrm{Lu}$ had the excess of continuing to wear mourning after the period had ended, and Bo Yu had the error of continuing to weep after he had removed his mourning attire. Comparing Shi to them, there is nothing for which he should be ashamed. ${ }^{51}$

49. Du You (1988): chap. 94, 2546-2547. For accounts of the tensions between wives and their respective offspring in the Zhong household, see Chen Shou (1959): chap. 28, 784, where Pei Songzhi 裴松之 cites the Wei shi chun qiu 魏氏春秋 and Zhong Hui's biography of his mother.

50. Du You (1988): chap. 89, 2452.

51. Du You (1988): chap. 94, 2553-2555. The quoted passage is on 2553. On the cases of Bo Yu and $\mathrm{Zi} \mathrm{Lu}$, routinely cited as classical precedents for emotions superseding ritual norms, see Li ji zhushu (1974): “Tan gong shang 檀弓上,” chap. 6, 24a; chap. 7, 2a. 
Here the classical precedents of Confucius's disciples serve to justify allowing emotional commitments to a mother to trump ritual dictates. Interestingly, Wang Shi's chief critic, Bian Hu, does not insist on the sanctity of the classics, but instead argues that the story of the father's deathbed permission was a fabrication to cover up Wang Shi's inability to live together with his stepmother. Since she was not truly divorced, according to Bian $\mathrm{Hu}$, he in fact owed her an even longer period of mourning. It is noteworthy that this critic himself had a stepmother to whom he was so devoted that he refused to resume office until he had fulfilled the full period of mourning for her. ${ }^{52}$ Thus although there was a violent disagreement over how this case was to be judged, both sides concurred in granting highest honor to devotion to mothers.

One final piece of evidence for the increased emphasis on mother-son ties in mourning relations is the extensive discussion in the Jin and Southern Dynasties of the mourning obligations of half-brothers who shared the same mother. In ritual theory such people were members of distinct lineages and hence not close kin, if they were kin at all. The ritual classics provided no explicit teaching on such mourning obligations. One anecdote in the Record of Ritual discussed the issue, without offering a clear answer:

Gongshu Mu had a half-brother with the same mother but different fathers. The halfbrother died, and he asked Zi You [about how to mourn him]. Zi You said, "Might it be nine months?" Di Yi in the same circumstances asked Zi Xia, and Zi Xia said, "I have never heard anything about it. The people of Lu mourn for a year." Di Yi thus mourned for a year, and the fact that today we do the same is due to Di Yi's question. ${ }^{53}$

The text insists on the absence of a real answer. Zi You guesses, undercutting himself by posing his answer as a question. Zi Xia insists on his own ignorance, offering a local custom as a possible, but non-canonical, guide. Contemporary practice is then traced to this custom, which itself lacks textual or intellectual grounding. However, it is noteworthy that Zheng Xuan's Eastern Han commentary, our only real guide to actual Han practice, follows the period suggested by $\mathrm{Zi}$ You, rather than Zi Xia's answer that the Record of Ritual seems to embrace. ${ }^{54}$ Thus the status of half-brothers, who would usually belong to the same household but formally be part of distinct lineages, seemed to present a uniquely difficult case for Chinese ritual logic.

52. Fang Xuanling et al. (1974): chap. 70, 1867-1869. This contains a somewhat different version of the memorial also found in the Du You (1988): as well as further details of the case and of Bian Hu's life.

53. Li ji zhushu (1974): “Tan gong shang," chap. 8, 10a.

54. Zheng Xuan's rationale for supporting the nine-month figure is preserved in the commentary on the page cited in the preceding note. 
The difficulty is highlighted in the discussion of the issue by Wang Su (A.D. 195-256), the leading commentator on the classics in the immediate post-Han period:

When a mother remarries, then even her parents do not receive mourning [from her offspring]. This is what is meant by "those cut off from the lineage are not offered mourning." Only the mother herself is mourned, in what is referred to as "intimate connection." Half-brothers with different fathers and the same mother should not mourn one another. However, "when one dwells together with a stepfather, one mourns him for a year," so his sons should then receive nine-month mourning. There is no clear text on the matter in the ritual classics, which explains why Zi You hesitates before answering. ${ }^{55}$

Wang Su explicitly argues that half-brothers with the same mother are not kin. He justifies the possibility of mourning (as suggested by Zi You) with reference to a passage in the Ceremonies and Rites on stepfathers. This passage justifies wearing mourning for a stepfather if he contributes materially to the ancestral cult of his stepson's lineage. ${ }^{56}$ Thus according to Wang Su, a shared mother does not constitute a kin link, and such half-brothers are connected only by the material contribution that a father/stepfather makes to each of their distinct lineages.

Significantly, the ritual theorists on this question collected in the Tong dian all frame their discussion as attacks on Wang Su. Throughout the Jin and the Southern Dynasties, they insist repeatedly that ties to the mother are based on flesh and feeling, and that brothers who share a single mother are bound in that way, without any appeal to material contributions from a stepfather. Thus in the Jin dynasty Chunyu Rui wrote:

A stepfather has no kin ties [wu qin] to the stepson, but if he establishes a temple and sets up sacrifices, one still mourns him for a year. Comparing this with sharing the same womb, how could there be a way to separate [the half-brothers], but he wants to separate them and say they are not kin. On the basis of the principle that whether one lives together with the stepfather or separately will affect the length of mourning, half-brothers with the same mother should appropriately follow the same principle. If they lived separately, then nine-month mourning, but if they lived together and owe a debt of kindness for mutual nourishment, then one-year mourning. This seems close to human feelings [ren qing]. ${ }^{57}$

Thus he argues that the physical ties of a common womb is clearly a basis of kinship, and that material considerations are secondary, a position which he

55. Du You (1988): chap. 91, 2494-2495.

56. Yi li zhu shu (1974): "Sang fu," chap. 31, 1a.

57. Du You (1988): chap. 91, 2496. 
insists is in accord with "human feelings," which are here offered as the ultimate basis of judgments on ritual. He also manages to cleverly incorporate both the periods suggested in the anecdote involving Zi You and Zi Xia.

In the subsequent Song dynasty, Yu Weizhi wrote an even more scathing attack on Wang Su's denial of kinship through a common mother:

On the one hand to be kin through a common birth, and on the other "dwelling together with a stepfather," where one owes mourning due to his meritorious contribution, these two categories of mourning are completely different. To think that [half-brothers] mourn one another because of a common father/stepfather is to completely miss the point! Ma Zhao said, "Half-brothers with different fathers are bound in a debt of kindness/ gratitude [en xi] through their mother, not through the father/stepfather. A stepfather is of a different lineage, but being born from the same mother they are thereby linked as kin. Even if they live apart, they should mourn one another. Wang Su thinks that they should mourn one another on account of the father/stepfather, and also says they must live together [to justify mourning], but this is to completely miss the point!" $\mathrm{Zi}$ You and $\mathrm{Zi} \mathrm{Xia} \mathrm{said} \mathrm{that} \mathrm{mourning} \mathrm{should} \mathrm{be} \mathrm{for} \mathrm{a} \mathrm{full} \mathrm{year} \mathrm{or} \mathrm{for} \mathrm{nine} \mathrm{months,} \mathrm{so} \mathrm{they}$ tended towards a different severity, but there was no doubt at all that they were kin. ${ }^{58}$

Here both Yu Weizhi and Ma Chao attack Wang Su in the strongest possible terms, repeatedly insisting that it is the common mother who links halfbrothers as kin, and that the father has nothing to do with it. Writing later in the Qi dynasty, Zhang Rong stated:

They share the same mother, so there is nine-month mourning. And [Wang] Su says it is based on a one-step reduction from the mourning owed a stepfather; how could this be human feeling [ren qing] ? ${ }^{59}$

These arguments about the mourning obligations of half-brothers highlight an underlying feature that is common to all these revisions of mourning doctrine in the centuries following the collapse of the Han. The new stress on the mother-son ties, and the insistence that mothers were owed mourning whatever their status in the household and whether or nor they had been divorced, all converged in a re-definition of the nature of kinship.

In the earlier, canonical doctrines, all kin ties passed through the father, and the sons mourning obligations for mothers or relatives by marriage depended on their relation to the father. To insist that 1) an heir owed full mourning obligations to his birth-mother, even if she was a concubine and thus subordinate to the primary wife (who was formally the true mother of the offspring of all the wives, and if a concubine's son became the heir would be declared the only

58. Du You (1988): chap. 91, 2496.

59. Ibid. 
and actual mother of that child), 2) that a woman who had been expelled from the lineage by the father should still receive mourning, and 3) that half-brothers were linked entirely through their shared mother without regard to the father/ stepfather, all of these arguments converged in the assertion that the motherson tie formed a deep and unchallengeable bond that existed independently of the father and the formal lineage structure. These arguments were particularly striking in that they focused on the heir, who in early thought was explicitly treated as the exact double of the father and, in some texts, described as being a "single body" with him. ${ }^{60}$ Thus suggesting that the heir's links with the mother stood on a par with, or took precedence over, those of the father was truly a remarkable assertion. While such beliefs had always been subliminally present in the structure of the individual Chinese households, their full elaboration and articulation were features of the late Eastern Han and the subsequent centuries.

\section{Conclusion}

The materials gathered above indicate that articulated attitudes towards the mother-son relation began to significantly change in the Eastern Han, particularly in the second century A.D., and continued to evolve over the following centuries. This had several causes. First, and probably least significant, the de facto institutionalization of the power of imperial affines in the second century made mother-son ties a routine element of political power in the court. As a consequence, discussions or disputes over the balance of power between the different factions in the period made increasingly frequent reference to motherson ties, now openly asserted as by nature the strongest form of emotional kin bond and as decisive to the political and social order.

More important was the belief in the shared substance of mother and son, as exemplified in the wide dissemination of the story of Master Zeng's filial devotion to his mother, and its evolution into a fundamental, multi-formed literary topos or even a myth of ideal mother-son ties. This explicit celebration and endorsement of the mother-son tie as the highest and most natural of human bonds had become a standard theme in several literary genres by no later than the fifth century A.D. This transformed the standard and hitherto authoritative idea in the canonical literature, in which the mother-son tie is treated as secondary to the masculine lineage defined in mourning regulations.

Third, by the second half of the second century A.D., even the patterns of mourning that had hitherto focused on the masculine patriline were also

60. On the son as a double of the father in early myth and political thought, see Lewis (2006b): 94-106. 
transformed by the passionate articulation of the mother-son tie in the emergent genre of the funeral inscription, as well as in related anecdotes in the literary sources. As noted above, whereas filial piety towards a father was noted in brief accounts of the complete performance of ritual duties, devotion towards mothers was marked in many inscriptions by graphic descriptions of the intense sufferings of the filial son, sufferings which were marked by the weeping of blood, the decline of health, and sometimes even death. This marking with the most extreme outpouring of feeling what had hitherto been treated as a secondary, purely private relationship, while the previously highest ties in mourning rules became a matter of mere duty, suggests a significant change in Chinese society in this period.

The exact nature of this change, however, is nowhere clearly articulated, so we can only engage in informed speculation. First, in part the emergence of these stories and genres is simply the articulation of ideas and feelings that had always existed but had not hitherto been regarded as suitable for treatment in literature and philosophy. Love between mothers and sons is an universal feature of human society, which varies only in the manner in which it is expressed and the forms in which it is articulated. However, this observation simply defers the question, for we must still ask what factors pressed male writers to articulate in literature feelings that had hitherto been ignored.

A second factor has been pointed out by Miranda Brown. As she has demonstrated, from the middle of the Western Han, the Han court and the political elite increasingly identified obligations towards fathers with official duties. Fathers were more and more clearly identified as lesser images of the ruler, obliged to be distant and severe, and their ties to their sons thus increasingly identified as based on education and discipline. This produced an ever clearer asymmetry between the devotion owed to one's father, which was precisely the ruleprescribed forms of discipline and duty noted in the inscriptions, and that which one owed to one's mother, which was based entirely on personal bonds of emotion and sentiment. ${ }^{61}$ As the literary elite became increasingly alienated from a court that was dominated by eunuchs and affines, the absolute superiority hitherto assigned to the court, a superiority within which filial duties towards fathers had become enmeshed, was openly challenged. In its place, local and regional networks based on personal and kin ties came increasingly to the fore as the most important sphere for elite political action. ${ }^{62}$ Thus personal ties and bonds of emotions became the basis of public life.

61. Brown (2007): 82-84. On this gendered asymmetry in ties between parents and offspring, see also Lewis (2006a): 104-116.

62. Lewis (2006a): 212-229. 
This development, and its links to the new emphasis on mother-son ties, is given its clearest expression in accounts of the career of Guo Tai. This man is best known as the most eminent leader of the "pure critique [qing yi]" movement of political discourse that emerged in opposition to the eunuch-dominated court. Like other members of this movement, he was celebrated for his conversational skills and his ability to judge human character. In this way, he and his fellows were the pioneers of the new emphasis on conversation and the assessment of character that gradually crystallized in the institution of Nine Ranks and Impartial Judges which became the dominant form of selection for office in the Northern and Southern Dynasties, and which underpinned the so-called "aristocracy" of the period. ${ }^{63}$ Notably, Guo Tai was also celebrated as a filial son, and Fan Pang stated that by constantly refusing office at court he remained "hidden from the world, without abandoning his mother, pure but not cutting himself off from the common." The biographies of many other Eastern Han figures also link refusal to take up office with the desire to stay at home and serve their mothers. ${ }^{64}$

In addition to this explicitly political role, the new emphasis on the emotional bonds of mother and son also signals an increasing perception that the conventional order of the period was in some way corrupt or lacking. In the Warring States and early Western Han, emotions had generally been viewed with suspicion, and participation in the state sphere was associated with an ability to control emotional responses to the world of sense experience. Such an ability was explicitly held to distinguish educated members of the elite from the common rabble. However, emotions were granted one legitimate place during this period as a response to failures or breakdown in the public sphere. Thus interpretations of the Canon of Poetry as a mode of political criticism, as well as the poetic topos of the "scholar's resentment" that was articulated in the Songs of the South and assorted rhapsodies both justified marked emotion as a literary response to failures or corruption in the political order. Similarly, the poems dealing with goddesses and beautiful women attributed to Song Yu and

63. On this development, see Lewis (2009a): 38-46. On Guo Tai, specifically, see 46, 241.

64. Fan Ye (1984): chap. 68, 2225-2227; chap. 39, 1309 (Jiang Ge persuades bandits to spare him because he is caring for his old mother, then refuses a post in order to care for her, sleeps by her grave, keeps on his mourning garments after term); chap. 39, 1311 (Zhou Pan declines posts to care for his mother, almost dies from grief when she dies); chap. 79b, 2584 (Xie Gai resigns from his post to take care of his aging mother and father); Hong Gua, Li shi: chap. 11, 19b; Yuan Hong (1987): chap. 11, 299 (declines a post to fulfill ritual obligations to his mother); Cai Zhonglang ji: chap. 4, 15a-17a. 
Sima Xiangru displayed emotion for purposes of critique or parody ${ }^{65}$ In these literary works emotions were imagined or invoked to constitute interpersonal ties where the normative processes of assigning roles had failed.

The same role of using emotion to create bonds where normative regulations were lacking or had failed informed the rising emphasis on mother-son ties. While the funerary inscriptions on mothers were not visibly critical of social breakdown, they did articulate an emotional/social bond that had been largely overlooked, and as noted above their sentiments were politicized. Thus emotion was here invoked precisely because the mother-son relation, in its true strength and form, had no formal mode of articulation in the received ritual and literary system, which had become corrupt. This factor helps to account for the fact that Cai Yong's inscriptions repeatedly insist on the difficulty of knowing where the mother's soul is, since she lacks a clear place in the old lineage order. ${ }^{66}$

In addition to emerging from these political developments and perceptions of breakdown, the increasing focus on mother-son ties and the public proclamation or performance of the feelings that bound the two together were also expressions of the increasing centrality of emotional ties to self-definition and to the definition of social groups. As to the former, the new centrality of emotions in forming ties and networks in the public sphere figures in the accounts of the scholars and officials who retired or were driven from the court by the eunuch faction. Guo Tai and those linked to him were not only noted as textual scholars and filial sons, but also as devoted friends and colleagues who gathered large numbers of followers and cultivated these personal ties as the core of their public selves. The new importance of conversation was closely tied to the new emphasis on personal, emotional ties as definitive of the elite. ${ }^{67}$ Within a generation the emergence of lyric poetry by literati that mixed devotion to friends with the expression of strong feelings developed even further these links of elite status, social gatherings, and the articulation of passionate emotions. ${ }^{68}$ Thus the re-articulation of mother-son ties in terms of emotional intensity was part of a broader reworking of the public space in early imperial China through the elaboration of personal links and networks based on feeling and shared character.

The elaboration of the emphasis on mother-son ties in the subsequent centuries of division was based on the continuation of the same factors - the emphasis

65. These points will be discussed in the book that I am currently writing, Emotional Communities in Early China. See also Rouzer (2001): chap. 2.

66. This same topos of a wandering spirit figures in inscriptions about dead children. See Wu Hung (1995b): 80.

67. See the cases in the preceding note, which all cite the close personal ties and devoted followings of these men.

68. Lewis (2009a): 18-20, 225-232. 
on emotion and personal ties to constitute public networks in an age of weaker courts - as well as several additional factors. As already touched on above, the last century of the Han and the subsequent centuries are conventionally understood as the age of the "great families" in Chinese history, so the focus on the formation of the family, at the expense of the more formalized political realm, is not surprising. For this reason the scholars of the period devoted huge amounts of time and effort to re-interpreting the ritual classics, as exemplified in the discussion above. Third, in a household with multiple wives, where the sons and the mother depended on each other to become eminent, the powerful link between individual mothers and their offspring formed multiple units (uterine families) that were often in competition. ${ }^{69}$ Yet another role of mothers was their pivotal importance in the education of offspring, both literary training and moral transformation. All of these are depicted in the literature of the period, and all of them contributed to the increasing emphasis on the centrality of the mother-son bond that I have sketched out here.

69. These units, which she calls the "uterine family," have been analyzed by Margery Wolf as a feature of the late-imperial household. See Wolf (1972). 
Mothers and Sons in Early Imperial China

\section{BibLIOGRAPHY}

BAN Gu 班固 et al. (1975). Dong guan Han ji 東觀漢記. Taipei: Shangwu, “Siku quanshu zhenben jieji”.

BAN Gu 班固 (32-92) et al. (1994). Han shu 漢書. Beijing: Zhonghua.

BAPTANDIER Brigitte (2008). The Lady of Linshui: A Chinese Female Cult, Kristin Ingrid FRYKLUND (trans.). Stanford: Stanford University.

Brown Miranda (2007). The Politics of Mourning in Early China. Albany: SUNY Press. CHEN Shou 陳壽 (1959). San Guo zhi 三國志. Beijing: Zhonghua.

Chun qiu Zuo zhuan zhu 春秋佐傳注 (1981), Yang Bojun 楊伯峻 (ed.). Beijing: Zhonghua.

Du You 杜佑 (735-812) (1988). Tong dian 通典. Beijing: Zhonghua.

Ebrey, Patricia (1986). The Economic and Social History of Later Han. In The Cambridge History of China. Vol. I: The Ch'in and Han Empires. Cambridge: Cambridge University Press: 637-645.

FANG Xuanling 房玄齡 (579-648) et al. (1974). Jin shu 晉書. Beijing: Zhonghua.

FAN Ye 范瞱 (398-445) (1984). Hou Han shu 後漢書. Beijing: Zhonghua.

GAN Bao 干寶 (1979). Sou shen ji. Beijing: Zhonghua.

HoNG Gua 洪适 (1117-1184). Li shi 隸釋, SBCK (ed.).

Huainanzi 淮南子(1974). In Xin bian zhuzi jicheng 新編諸子集成, vol. VII. Taipei: Shijie.

Kaga Eiji 加賀榮治 (1964). Chūgoku koten kaishaku shi: Ishin hen 中國古典解釋史: 魏晉篇. Tokyo: Keisō Shobō.

LewIS Mark Edward (1999). Writing and Authority in Early China. Albany: SUNY Press.

Lewis Mark Edward (2006a). The Construction of Space in Early China. Albany: SUNY Press.

LEwIS Mark Edward (2006b). The Flood Myths of Early China. Albany: SUNY Press.

LewIS Mark Edward (2009a). China Between Empires: The Northern and Southern Dynasties. Cambridge, Mass.: The Belknap Press of Harvard University Press.

Lewis Mark Edward (2009b). China's Cosmopolitan Empire: The Tang Dynasty. Cambridge, Mass.: The Belknap Press of Harvard University Press.

Li ji zhushu 禮記注疏 (1974). In Shisan jing zhushu 十三經注疏. Taipei: Yiwen.

LI Yanshou 李延壽 (7th century) (1975). Nan shi 南史. Beijing: Zhonghua.

Linghu Defen 令狐德荣 et al. (1971). Zhou shu 周書. Beijing: Zhonghua.

Lü shi chun qiu jishi 呂氏春秋集釋 (1984). Chen Qiyou 陳奇猷 (ed.). Shanghai: Xuelin.

Rosenwein Barbara H. (2006). Emotional Communities in the Early Middle Ages. Ithaca: Cornell University Press.

Rouzer Paul (2001). Articulated Ladies: Gender and the Male Community in Early Chinese Texts. Cambridge (Mass.): Harvard University Press.

SHEN Yue 沈約 (1974). Song shu 宋書. Beijing: Zhonghua.

WANG Chong 王充 (1957). Lun heng ji jie 論衡集解, Liu Pansui 劉盼遂 (ed.). Beijing: Guji.

WANG Wentai 汪文臺 (1796-1844) (1972). Qi jia Hou Han shu 七家後漢書. Taipei: Wenhai.

WEI Shou 魏収 (1974). Wei shu 魏書. Beijing: Zhonghua. 
Wolf Margery (1972). Women and the Family in Rural Taiwan. Stanford: Stanford University Press.

Wu Hong (1995a). Monumentality in Early Chinese Art and Architecture. Stanford: Stanford University Press.

Wu Hung (1995b). Private Love and Public Duty: Images of Children in Early Chinese Art. In Anne Behnke Kinney (ed.), Chinese Views of Childhood. Honolulu: University of Hawai'i Press.

Xiao jing zhushu 孝經注疏 (1976), Xing Bing 邢旵 (932-1010) (ed.). In Shisan jing zhushu. Taipei: Yiwen.

XIE Cheng 謝承 (1972). Hou Han shu. Preserved in WANG Wentai 汪文臺 (1796-1844), Qi jia Hou Han shu 七家後漢書. Taipei: Wenhai.

YAO Cha 姚察 and Yao Silian 姚思廉 (557-637) (1973). Liang shu 梁書. Beijing: Zhonghua.

Yi li zhu shu 儀禮注疏 (1974). In Shisan jing zhushu 十三經注疏, compiled by Ruan Yuan 阮元 (1764-1849). Taipei: Yiwen.

Yuan Hong 袁宏 (128-184) (1987). Hou Han ji 後漢記. Tianjin: Tianjin gu ji. 


\section{GLOSSARY}

bao tai hou 保太后

bu gan zhi sui si huai, yi que wang xian 不敢執遂私懷, 以閶王憲 de sui xi qing 得遂私情

en 恩

en xi 恩繋

gan 感

gan tong 感通

gan ying 感應

gong yi 公義

guan guo zhi ren 觀過知仁

huang tai hou 皇太后

Lie nü zhuan 烈女傳

ming tong 冥通

mu yi zi gui 母以子貴

qin 親

qing yi 清議

shen ming 神明

si ai 私愛

si qi si qing 肆其私情

si zun 私尊

Sou shen ji 搜神記

$\mathrm{su}$ 俗

tong 通

tong qi 同氣

tong qi yi xi, gu rou zhi en 同氣異息, 骨肉之恩

wang 王

xing jian ke shao en qing 性儉攰少恩情

zhi 志

zhi 至

zhi gong zhi yi 至公之義

zhi qin 至親

zhi zun 至尊 
